\title{
Hydrogen bioproduction with anaerobic bacteria consortium from brewery wastewater
}

\author{
Renan Pachiega ${ }^{a, b, *}$, Mayara Franco Rodrigues ${ }^{a}$, \\ Caroline Varella Rodrigues ${ }^{a, b}$, Isabel Kimiko Sakamoto ${ }^{c}$, \\ Maria Bernadete A. Varesche ${ }^{c}$, José Eduardo De Oliveira ${ }^{b, d}$, \\ Sandra Imaculada Maintinguer ${ }^{\text {be }}$ \\ ${ }^{a}$ Institute of Chemistry - IQ UNESP, Prof. Francisco Degni 55, 14801-970, Araraquara, SP, Brazil \\ ${ }^{\mathrm{b}}$ Bioenergy Research Institute - IPBEN, UNESP, 13550-230, Rio Claro, SP, Brazil \\ ${ }^{c}$ Department of Hydraulics and Sanitation, School of Engineering of São Carlos, University of São Paulo, Av. João \\ Dagnone, 1100, Jd. Santa Angelina, 13563-120, São Carlos, SP, Brazil \\ d Center for Monitoring and Research of the Quality of Fuels, Biofuels, Crude Oil, and Derivatives, Institute of \\ Chemistry - CEMPEQC, UNESP, Prof. Francisco Degni 55, 14801-970, Araraquara, SP, Brazil \\ e University of Araraquara, R. Voluntários da Pátria, 1309, 14801-320, Araraquara, SP, Brazil
}

\section{A R T I C L E I N F O}

Article history:

Received 28 November 2017

Received in revised form

13 February 2018

Accepted 18 February 2018

Available online 16 March 2018

Keywords:

Agroindustrial wastewater

Firmicutes

Veillonella

$\mathrm{bioH}_{2}$

Subtropical mix culture

\begin{abstract}
A B S T R A C T
Biohydrogen production is a cheap and clean way to obtain hydrogen gas. In subtropical countries such as Brazil the average temperatures of $27^{\circ} \mathrm{C}$ can favor the hydrogen producing bacteria growth. A mixed culture was obtained from a subtropical sludge treating brewery wastewater and anaerobic batch reactors were fed with glucose, sucrose, fructose and xylose in low concentrations $\left(2.0,5.0\right.$ and $\left.10.0 \mathrm{~g} \mathrm{~L}^{-1}\right)$ at $37^{\circ} \mathrm{C}$, initial pH 5.5 and headspace with $\mathrm{N}_{2}$ $(99 \%)$ to maintain the anaerobic conditions. The inoculum was a subtropical granulated sludge from UASB (Upflow Anaerobic Sludge Blanket) reactor treating brewery wastewater. The higher $\mathrm{H}_{2}$ yields were obtained in reactors operated with 2 and $5 \mathrm{gL}^{-1}$ of fructose and they were $1.5 \mathrm{~mol} \mathrm{H}_{2} \mathrm{~mol}^{-1}$ of fructose and $1.3 \mathrm{~mol} \mathrm{H}_{2} \mathrm{~mol}^{-1}$ of sucrose, respectively. The volatile fatty acids (VFA) generated at the end of operation were, predominantly, butyric and acetic acid, indicating the favoring of the metabolic route of hydrogen generation by the consortium of anaerobic bacteria from the brewery wastewater. Biomolecular analyses revealed the predominance of hydrogen producing bacteria from Firmicutes phylum distributed in the families Streptococcaceae, Veillonellaceae and uncultured bacteria. These results confirm future applications of subtropical sludges with agroindustrial wastewaters containing low concentrations of sugars on hydrogen generation.
\end{abstract}

() 2018 Hydrogen Energy Publications LLC. Published by Elsevier Ltd. All rights reserved.

\section{Introduction}

Fossil fuels have been the dominant source of energy reaching $87 \%$ of worldwide consumption [1]. Hydrogen is an important alternative source of energy which has been studied for several researches as a renewable, sustainable energy source [2] to replace fossil fuels, such as coal, oil, and natural gas. The hydrogen gas appears as a friendly and sustainable fuel [3].

\footnotetext{
* Corresponding author. Institute of Chemistry - IQ, UNESP, Prof. Francisco Degni 55, 14801-970, Araraquara, SP, Brazil.

E-mail addresses: renanpachiega@gmail.com (R. Pachiega), mainting2008@gmail.com (S.I. Maintinguer).
} 
The combustion of hydrogen gas only generates water and energy, showing the potential against the greenhouse gases which are generated in the combustion of fossil fuels [4]. The hydrogen gas can be obtained by several processes as thermochemical and electrochemical, however it is possible to point the bio production, which uses microorganisms for dark and photo fermentation, as the cheapest one.

Subtropical countries as Brazil have average temperatures of $27{ }^{\circ} \mathrm{C}$, which may be considered ideal for growth of hydrogen producing anaerobic bacteria [5]. Among the studies that have been carried out on biohydrogen production various kinds of sludges can be cited from wastewater treatment plant [6], from swine wastewater treatment plant [7], from the treatment of stillage from sugarcane [8], among others. However, there are just a few applications with subtropical sludges on hydrogen generation by dark fermentation.

Beer is pointed as one of the most consumed beverages worldwide. It loses just for tea, milk and coffee [9]. Brazil has a large beer production, reaching 13 billion of liters of beer per year. For $1 \mathrm{~L}$ of beer 3-10 L of effluent is generated, which may vary with the steps followed by the production process [9]. Effluents from beer industries have been treated by biological processes, whose diversity of anaerobic microorganisms contain anaerobic bacteria capable on biogas generation, mainly hydrogen gas. Besides that, Clostridium sp. is known as a great biohydrogen producer [10] but the consortium of anaerobic bacteria could be in some cases greater than the isolated microorganisms. Some interactions among the microorganisms are still unknown [11] and they can contribute with high potential of microorganisms for bioconversion from sugars into biohydrogen.

The dark fermentation using wastewater with carbohydrates, mainly sugars, as feed stock have different yields for each kind of substrate presented in two metabolic routes with generations of acetic and/or butyric acids. In this sense, glucose, fructose (glucose isomer), sucrose and xylose can be converted, respectively, in 4, 4, 8 and $6 \mathrm{~mol}$ of $\mathrm{H}_{2}$ per mole of carbohydrate in metabolic route of acetic acid (Eqs (1)-(3)). However, in the metabolic route of butyric acid generation can be obtained, respectively, 2, 2, 4 and $5 \mathrm{~mol}$ of $\mathrm{H}_{2}$ per mole of glucose, fructose (glucose isomer), xylose and sucrose (Eqs (4)-(6)), respectively $[7,12,13]$.

$$
\begin{aligned}
& \mathrm{C}_{6} \mathrm{H}_{12} \mathrm{O}_{6}+2 \mathrm{H}_{2} \mathrm{O} \rightarrow 2 \mathrm{CH}_{3} \mathrm{COOH}+4 \mathrm{H}_{2}+2 \mathrm{CO}_{2} \\
& \mathrm{C}_{12} \mathrm{H}_{22} \mathrm{O}_{11}+5 \mathrm{H}_{2} \mathrm{O} \rightarrow 4 \mathrm{CH}_{3} \mathrm{COOH}+4 \mathrm{CO}_{2}+8 \mathrm{H}_{2} \\
& \mathrm{C}_{5} \mathrm{H}_{10} \mathrm{O}_{5}+3 \mathrm{H}_{2} \mathrm{O} \rightarrow \mathrm{CH}_{3} \mathrm{COOH}+3 \mathrm{CO}_{2}+6 \mathrm{H}_{2} \\
& \mathrm{C}_{6} \mathrm{H}_{12} \mathrm{O}_{6}+2 \mathrm{H}_{2} \mathrm{O} \rightarrow \mathrm{CH}_{2} \mathrm{CH}_{2} \mathrm{CH}_{2} \mathrm{COOH}+2 \mathrm{H}_{2}+2 \mathrm{CO}_{2} \\
& \mathrm{C}_{12} \mathrm{H}_{22} \mathrm{O}_{11}+\mathrm{H}_{2} \mathrm{O} \rightarrow 2 \mathrm{CH}_{3} \mathrm{CH}_{2} \mathrm{CH}_{2} \mathrm{COOH}+4 \mathrm{CO}_{2}+4 \mathrm{H}_{2} \\
& \mathrm{C}_{5} \mathrm{H}_{10} \mathrm{O}_{5}+2 \mathrm{H}_{2} \mathrm{O} \rightarrow 1 / 2 \mathrm{CH}_{3} \mathrm{CH}_{2} \mathrm{CH}_{2} \mathrm{COOH}+3 \mathrm{CO}_{2}+5 \mathrm{H}_{2}
\end{aligned}
$$

The sugars such as fructose, glucose, sucrose and xylose are present in agricultural, industrial and domestic wastes are rich in carbohydrate and thus offer a potential resource for dark fermentation [4] using wastewaters from Brazil which are rich in organic matter as well as in nutrient compounds, as described previously. Agricultural wastes are mainly composed of cellulose, hemicellulose and lignin [14]. Brazil is the biggest citrus producer worldwide reaching 16 million tons in 2014, which represent $33 \%$ of worldwide production. São Paulo State represents $73 \%$ of this production. However, this large production also produces large amount of wastes, reaching 8.4 million tons on orange processing in the same period. Citric wastewater contains representative concentrations of glucose and fructose (12 $\mathrm{g} \mathrm{L}^{-1}$ and $4 \mathrm{~g} \mathrm{~L}^{-1}$, respectively) [15]. Also in São Paulo State, Brazil, ethanol and sugar industries are one of the most important agroindustrial field, producing 23.5 billion litters of ethanol and 596 million tons of sugar in 2012 [16]. Allied with ethanol production is the vinasse production that reached 305.5 billion of litters in the same period [17] and this waste produced in agroindustrial sector can be applied on hydrogen production due to its concentration of glucose, sucrose and fructose (22-45 g L ${ }^{-1}$ COD) [18]. This process has to be done with some caution, mainly, because of the inhibitory compounds present in distillery wastes, which can be a barrier to the anaerobic digestion process [19]. An adjustment period is advisable to the bacteria consortia growth allied with the complex and/or inhibitory compounds. The Brazilian paper industries are important and predominant market in South America, producing 10.4 million tons in 2014 [20]. The pulp and paper industries applied pretreatments on lignocellulosic material which release carbohydrates on its wastewater [21]. The pre-treatments could include composting with of fungi aiming an efficient degradation of organic matter, which occur in nature in a very slow speed [14]. Major components of lignocellulosic hydrolysate include hexose (glucose) and pentose (xylose and trace amount of arabinose), xylose which can be used as carbon source on biohydrogen production [21,22]. Therefore, the use of these wastewaters by dark fermentation processes for hydrogen production allows the production of clean renewable sources of energy and wastewater treatment, minimizing the cost of both processes.

In this sense, the objectives of this study were to obtain a consortium of anaerobic hydrogen producing bacteria using a subtropical granulated sludge from an UASB (Upflow Anaerobic Sludge Blanket) reactor treating brewery wastewaters; to investigate hydrogen generation with a consortium of anaerobic bacteria in anaerobic batch reactors fed with low concentrations of sugar which are similar to Brazilian wastewaters found in agricultural effluents and; to identify and to characterize the consortium of anaerobic bacteria responsible for hydrogen production.

\section{Material and methods}

\section{Inoculum}

The source of inoculum was a subtropical granulated sludge from an UASB reactor treating brewery wastewater on a beer factory (Araraquara, São Paulo, Brazil) with the following characterization: $\mathrm{BOD}\left(\mathrm{mg} \mathrm{O}_{2} \mathrm{~L}^{-1}\right)$ 1597; $\mathrm{COD}\left(\mathrm{mg} \mathrm{O}_{2} \mathrm{~L}^{-1}\right)$ 2552; VFA (mg $\mathrm{CaCO}_{3} \mathrm{~L}^{-1}$ ) 473; $\mathrm{pH} \mathrm{5,65}$. The granulated sludge was broken, separately, in a mortar and pestle and then it was 
reactivated in anaerobic batch reactors containing culture medium, according described below, at $37^{\circ} \mathrm{C}$ for $168 \mathrm{~h}$.

\section{Reactivation and pretreatment of the inoculum}

Triplicates of anaerobic batch reactors $(100 \mathrm{~mL})$ were fed with culture medium (50 mL), (g L ${ }^{-1}$ : 10-glucose, 5-yeast extract, 5peptone and 5-meat extract), headspace $(50 \mathrm{~mL})$ was filled with $\mathrm{N}_{2}(99.99 \%)$ to maintain the anaerobic conditions, initial $\mathrm{pH}$ 7.0, capped with butyl rubber stoppers and they were sterilized $\left(20 \mathrm{~min}\right.$, at $\left.120^{\circ} \mathrm{C}\right)$.

After the reactivation period the anaerobic batch reactors were opened and the sludge were submitted to a heat treatment [23]. The reactivated sludge was added into a beaker under magnetic agitation and $100{ }^{\circ} \mathrm{C}$ per $10 \mathrm{~min}$. The heated sludge was cooled to the ambient temperature $\left(25^{\circ} \mathrm{C}\right)$ in ice bath. The inoculum was transferred to the anaerobic batch hydrogen reactors using sterile syringes.

\section{Enrichment of anaerobic bacteria consortium}

Amounts $(20 \% \mathrm{v} / \mathrm{v})$ of the pretreated inoculum were inoculated in anaerobic batch reactors $(100 \mathrm{~mL})$ for 7 days, under $\mathrm{pH}$ 5.5 at $37{ }^{\circ} \mathrm{C}$. Serial dilution process was done repeatedly focused on the enrichment of the $\mathrm{H}_{2}$-producing bacteria. The $\mathrm{pH}$ values and cellular growth were performed, based on the optical density at $600 \mathrm{~nm}\left(\mathrm{OD}_{600}\right)$ [24]. Microscopy analyses were made to monitor the morphologies of anaerobic bacteria consortium.

The consortia of anaerobic bacteria were centrifuged (9000 rpm at $4{ }^{\circ} \mathrm{C}$ for $6 \mathrm{~min}$ ) and the cell pellets were suspended in new culture medium [25], with the following composition $\left(\mathrm{g} \mathrm{L}^{-1}\right)$ : Solution A $\left[\mathrm{NiSO}_{4} \cdot 6 \mathrm{H}_{2} \mathrm{O}\right.$ (0.50), FeS$\mathrm{O}_{4} \cdot 7 \mathrm{H}_{2} \mathrm{O}$ (2.50), $\mathrm{FeCl}_{3} \cdot 6 \mathrm{H}_{2} \mathrm{O}(0.25), \mathrm{CoCl}_{2} \cdot 2 \mathrm{H}_{2} \mathrm{O}(0.04)$ ]; Solution B $\left[\mathrm{CaCl}_{2} \cdot 6 \mathrm{H}_{2} \mathrm{O}\right.$ (2.06)]; Solution C $\left[\mathrm{SeO}_{2}\right.$ (0.14)]; Solution D $\left[\mathrm{KH}_{2} \mathrm{PO}_{4}\right.$ (5.36), $\mathrm{K}_{2} \mathrm{HPO}_{4}$ (1.30), $\mathrm{Na}_{2} \mathrm{HPO}_{4} \mathrm{H}_{2} \mathrm{O}$ (2.76) two vitamin solutions ( $\mathrm{mg} \mathrm{L}^{-1}$ ); solution E [biotin (10.0); p-aminobenzoic acid (40.0)]; and solution F [B12 vitamin (40.0)] [9]. The culture media contained peptone $\left(1.0 \mathrm{~g} \mathrm{~L}^{-1}\right)$, urea $\left(0.04 \mathrm{~g} \mathrm{~L}^{-1}\right)$ and solutions $\left(\mathrm{mL}^{-1}\right)$ : A 2.0, B 2.0, C 2.0, D 2.0, vitamin solutions (E) 2.0, (F) 2.0 [10]. The $\mathrm{pH}$ was adjusted to 5.5 with the addition of $\mathrm{NaOH}(1 \mathrm{M})$ or $\mathrm{HCl}(1 \mathrm{M})$. The culture medium was filtered through a previously sterilized $0.22 \mu \mathrm{m}$ Millipore membrane. This setup was presented in a previous work [26].

\section{Operation of anaerobic batch reactors}

Anaerobic batch reactors (2 L) capped with butyl rubber stoppers were fed with sucrose, fructose, xylose and glucose (2 and $5 \mathrm{~g} \mathrm{~L}^{-1}$ ) and operated in triplicates. One extra assay was carried out with sucrose $10 \mathrm{~g} \mathrm{~L}^{-1}$ at the same configurations already cited. The headspace ( $1 \mathrm{~L}$ ) was purged with $\mathrm{N}_{2}$ (99.99\%) during $20 \mathrm{~min}$. They were kept at $37^{\circ} \mathrm{C}$, during almost $220 \mathrm{~h}$.

\section{Chromatographic analyses}

The hydrogen, methane and $\mathrm{CO}_{2}$ gases contents in the biogas were determined simultaneously in a single gas chromatography ran in a TOGA - Transformer Oil Gas Analyzer - system, attached with a Trace GC Ultra -Thermo Gas
Chromatograph - equipped with split/splitless injector and two detectors: thermal conductivity detector (TCD) and flame ionization detector (FID), with methanizer [27]. The fraction containing hydrogen, nitrogen, and methane was analyzed in a Rt-MSieve $5 \mathrm{~A}^{\circ} 30 \mathrm{~m} \times 0.53 \mathrm{~mm}$ i.d. column. Hydrogen and nitrogen were detected by the TCD. $\mathrm{CO}_{2}$ was detected by the FID after passing through the methanizer. Argon was used as carrier gas (1.5 mL $\mathrm{min}^{-1}$ in splitless mode). The FID temperature was $250^{\circ} \mathrm{C}$; the TCD and injector were adjusted to $150^{\circ} \mathrm{C}$. The oven programing was $50{ }^{\circ} \mathrm{C}$ (4.5 min), heating from $40^{\circ} \mathrm{C} \mathrm{min}{ }^{-1}$ to $180^{\circ} \mathrm{C}(1.5 \mathrm{~min})$ then cooling from $50^{\circ} \mathrm{C} \mathrm{min}^{-1}$ to $50^{\circ} \mathrm{C}(3.15 \mathrm{~min})$.

VFA and alcohol concentrations were measured by gas chromatography, using a Shimadzu gas chromatograph (GC model 2010), equipped with a flame ionization detector, a COMBI-PAL headspace auto-sampler system (AOC 5000), and a HP-INNOWAX column $(30 \mathrm{~m} \times 0.25 \mathrm{~mm} \times 0.25 \mu \mathrm{m}$ of film thickness) [28].

\section{Analytical analyses}

Carbohydrates consumption was done following the Dubois et al. [29] method adapted by Herbert et al. [30]. The measurements were performed by spectrophotometry at $490 \mathrm{~nm}$ $\left(\mathrm{OD}_{490}\right)$.

Cellular growth measurements were carried out using spectrophotometry at $600 \mathrm{~nm}\left(\mathrm{OD}_{600}\right)$ according to APHA [24].

The final $\mathrm{pH}$ after the end of the assays were measured according to APHA [24].

\section{Data adjustment}

The experimental data were adjusted to their average values obtained from the triplicates of the anaerobic batch reactors using the Statistica ${ }^{\circledR}$ software. The maximum rate of biohydrogen production was obtained by a non-linear sigmoidal adjust of Gompertz function [31] showed below.

$$
\mathrm{H}=\mathrm{P} \cdot \exp \{-\exp \{[(\mathrm{Rm} \cdot e) / \mathrm{P}](\lambda-\mathrm{t})+1\}\}
$$

Therefore, $\mathrm{P}$ is the hydrogen production potential (mmol L ${ }^{-1}$ culture), $\mathrm{Rm}$ is the maximum rate of hydrogen production (mmol L $\mathrm{L}^{-1}$ culture. $\mathrm{h}^{-1}$ ), $\lambda$ is the lag phase, in hours, of $\mathrm{H}_{2}$ generation and $e$ is equal to 2,718281828 .

\section{Molecular biology analyses and sequences determination}

Samples of enriched inoculum were concentrated on centrifuge at $4{ }^{\circ} \mathrm{C}, 9000 \mathrm{rpm}$ for $10 \mathrm{~min}$. The pellet obtained was washed by sterile and pH 7.4 PBS buffer solution [32] and was maintained under $-20^{\circ} \mathrm{C}$. The DNA extraction was performed in chloroform phenol according to modified Griffiths et al. [33]. DNA concentration was done as follows: $1 \mathrm{~mL}$ of icy ethanol $95 \%$ was added and homogenized. In sequence, the sample was centrifuged (10000 rpm, $4{ }^{\circ} \mathrm{C}, 10 \mathrm{~min}$ ) and the supernatant was disposed. $500 \mu \mathrm{L}$ of icy ethanol $70 \%$ was added and centrifuged in the same conditions. The resulting supernatant was discarded, and the samples were let to dry. Then, with the samples dried, was added $50 \mu \mathrm{L}$ of TE buffer solution and maintained at $-20{ }^{\circ} \mathrm{C}$ for subsequent PCR amplification procedure. The amplification of the polymerase chain reaction 
(PCR) was performed with a 27F (50 AGA GTT TGA TCM TGG CTC AG e 30) and 1000R (50 - GGG TTG CGC TCG TTG - 30) [34]. Aiming to obtain the partial bacterial 16S rRNA gene sequences, was used the 27F-1100R primers [34] to identify the bacteria population using a thermocycler Eppendorf AG-22331 Hamburg. The setup was set as follows: pre-denaturation at $94{ }^{\circ} \mathrm{C}$ for $5 \mathrm{~min}$; with 30 cycles of denaturation at $94^{\circ} \mathrm{C}$ for $45 \mathrm{~s}$; annealing at $55^{\circ} \mathrm{C}$ for $45 \mathrm{~s}$; extension at $72{ }^{\circ} \mathrm{C}$ for $1 \mathrm{~min}$ and $45 \mathrm{~s}$; final extension at $72{ }^{\circ} \mathrm{C}$ for $7 \mathrm{~min}$; and cooling at $4{ }^{\circ} \mathrm{C}$.

The PCR products were sent to Macrogen Inc ${ }^{\circledR}$ for nucleotide sequence analysis. With the resulting PCR product, the cloning and sequencing processes were performed using the pGEM Easy Vector System I for Bacteria Domain. A comparative analysis was performed using the Ribosomal Database Project (RDP - http://rdp.cme.msu.edu/), and the Basic Local Alignment Search Tool (BLAST) was used to search the National Center for Biotechnology Information sequence database (http://www.ncbi.nlm.nih.gov/BLAST/). Ninety-eight sequences within 8 OTUs were found in this study. The sequences obtained were deposited in Genbank with accessing numbers from KY866665 to KY866672. The taxonomic identification of the sequences which represents the OTU were performed using the RDP-Classifier.

\section{Results and discussion}

\section{Reactivation and pretreatment of inoculum}

The heat treatment was efficient at inactivation of methanogenic bacteria and to maintain anaerobic bacteria with rods morphology. Song et al. [35] applied different pretreatments: infrared oven for $2 \mathrm{~h}$; 1:4 solid/liquid boiling for $30 \mathrm{~min}$; aeration for $72 \mathrm{~h}$ and aeration for $72 \mathrm{~h}$ adding sugar; using caw wastes as source of inoculum in anaerobic batch reactors to inactivate methanogenic microorganisms in anaerobic batch reactors fed with $10 \mathrm{~g} \mathrm{~L}^{-1}$ of sucrose at $\mathrm{pH} 7.0,36 \pm 1^{\circ} \mathrm{C}$. The authors observed no methane generation only to heat treated inoculum, such as in the present study, with a great increasing in biohydrogen production of $273.5 \mathrm{~mL} \mathrm{~g}^{-1}$ of substrate. Sá et al. [36] observed morphologies of rods after heat treatment of domestic sewage, such as in present study, and they concluded the anaerobic bacteria were involved in hydrogen production observed. Kawagoshi et al. [37]obtained similar results, such as the present study, during pretreatments of: $\mathrm{pH}$ reduction ( $\mathrm{pH} 3.0$ for $18 \mathrm{~h}$ ) and heat $\left(100{ }^{\circ} \mathrm{C}\right.$ for $2 \mathrm{~h}$ ) in six different bacteria sources (aerobic activated sludge from a sewage water treatment plant, anaerobic digested sludge, soil from watermelon field, soil from kiwi grove, lake sediment and aerobic refuse compost). The authors observed the best results for biohydrogen production in reactors with heat treated inoculum previously. In the present study, the headspace of anaerobic batch reactors contained $75 \% \mathrm{H}_{2}$ in the composition of biogas after $168 \mathrm{~h}$ of operation and no methane was detected during the chromatography analysis with the predominance of rods and cocci in the consortium of anaerobic bacteria (data not shown). These results confirmed the efficiency of the heat treatment applied in the subtropical granular sludge.

\section{Operation of anaerobic batch reactors}

The $\mathrm{H}_{2}$ generation in the anaerobic batch reactors fed with fructose 2.0 and $5.0 \mathrm{~g} \mathrm{~L}^{-1}$ had their maximum potential of generation (Table 1 and Fig. 1) of $13.8 \mathrm{mmol} \mathrm{H}_{2} \mathrm{~L}^{-1}$ and $26.1 \mathrm{mmol} \mathrm{H}_{2} \mathrm{~L}^{-1}$, respectively. These results were higher than the reactors operated with glucose 2.0 and $5.0 \mathrm{~g} \mathrm{~L}^{-1}$ (3.4 and $\left.4.2 \mathrm{mmol} \mathrm{H}_{2} \mathrm{~L}^{-1}\right)$, sucrose $2.0,5.0 \mathrm{~g} \mathrm{~L}^{-1}$ and $10.0 \mathrm{~g} \mathrm{~L}^{-1}(4.5,10.3$ and $13.3 \mathrm{mmol} \mathrm{H}_{2} \mathrm{~L}^{-1}$ ) and xylose 2.0 and $5.0 \mathrm{gL}^{-1}$ (3.4 and $\left.4.5 \mathrm{mmol} \mathrm{H}_{2} \mathrm{~L}^{-1}\right)$. In addition, the maximum production rate in reactor with fructose $\left(5.0 \mathrm{~g} \mathrm{~L}^{-1}\right)$ was $0.5 \mathrm{mmol} \mathrm{H} \mathrm{H}^{-1} \mathrm{~h}^{-1}$. These results with fructose indicated that the concentrations applied were not inhibitory for the bacteria consortium. Hence, the maximum potential of $\mathrm{H}_{2}$ generation followed a direct relation with the sugar concentrations for the reactors fed with fructose, xylose, glucose and sucrose. Subudhi et al. (2013) studied the bacterial strain Enterobacter cloacae DT-1 on hydrogen production using $10 \mathrm{~g} \mathrm{~L}^{-1}$ of glucose, $\mathrm{pH} 8.0$ at $37^{\circ} \mathrm{C}$, obtaining a maximum hydrogen of $32 \mathrm{mmol} \mathrm{H}_{2} \mathrm{~L}^{-1}$. These higher hydrogen production, compared to the present work of

\begin{tabular}{|c|c|c|c|c|c|c|c|c|c|}
\hline Studied parameter & $\begin{array}{l}\text { Fructose } \\
2.0 \mathrm{~g} \mathrm{~L}^{-1}\end{array}$ & $\begin{array}{l}\text { Fructose } \\
5.0 \mathrm{~g} \mathrm{~L}^{-1}\end{array}$ & $\begin{array}{l}\text { Glucose } \\
2.0 \mathrm{~g} \mathrm{~L}^{-1}\end{array}$ & $\begin{array}{l}\text { Glucose } \\
5.0 \mathrm{~g} \mathrm{~L}^{-1}\end{array}$ & $\begin{array}{l}\text { Sucrose } \\
2.0 \mathrm{~g} \mathrm{~L}^{-1}\end{array}$ & $\begin{array}{l}\text { Sucrose } \\
5.0 \mathrm{~g} \mathrm{~L}^{-1}\end{array}$ & $\begin{array}{l}\text { Sucrose } \\
10.0 \mathrm{~g} \mathrm{~L}^{-1}\end{array}$ & $\begin{array}{c}\text { Xylose } \\
2.0 \mathrm{~g} \mathrm{~L}^{-1}\end{array}$ & $\begin{array}{l}\text { Xylose } \\
5.0 \mathrm{~g} \mathrm{~L}^{-1}\end{array}$ \\
\hline Operation time $(\mathrm{h})$ & 239 & 238 & 169 & 143 & 169 & 238 & 189 & 160 & 215 \\
\hline Final $\mathrm{pH}$ & 3.7 & 3.5 & 4.5 & 4.5 & 4.4 & 4.4 & 4.3 & 4.2 & 4.3 \\
\hline Max. Growth $\left(\mathrm{OD}_{600}\right)$ & 0.20 & 0.37 & 0.13 & 0.24 & 0.19 & 0.54 & 0.1 & 0.22 & 0.11 \\
\hline${ }^{\mathrm{a}} \mathrm{P}\left(\mathrm{mmol} \mathrm{H}_{2} \mathrm{~L}^{-1}\right)$ & 13.8 & 26.1 & 3.4 & 4.2 & 4.5 & 10.4 & 13.3 & 3.4 & 4.5 \\
\hline${ }^{\mathrm{a}} \mathrm{Rm}\left(\mathrm{mmol} \mathrm{H}_{2} \mathrm{~L}^{-1} \mathrm{~h}^{-1}\right)$ & 0.1 & 0.5 & 0.2 & 0.3 & 0.2 & 0.1 & 0.2 & 0.2 & 0.04 \\
\hline${ }^{\mathrm{a}} \lambda(\mathrm{h})$ & 57.3 & 107.6 & 19.3 & 21.2 & 13.3 & 4.4 & 16.0 & 16.0 & 2.2 \\
\hline${ }^{a}{ }^{2}$ & 0.990 & 0.999 & 0.994 & 0.996 & 0.995 & 0.986 & 0.944 & 0.999 & 0.973 \\
\hline \% Sugar consumption & 73.7 & 59.2 & 87.1 & 71.5 & 88.7 & 67.1 & 49 & 88.50 & 80.1 \\
\hline Acetic acid $\left(\mathrm{mg} \mathrm{L}^{-1}\right)$ & 126.5 & 323.9 & 8.8 & 246.9 & 39.7 & 580.3 & 241.2 & 108.1 & 73.1 \\
\hline Butyric acid $\left(\mathrm{mg} \mathrm{L}^{-1}\right)$ & 199.9 & 296.9 & 17.8 & 95.5 & 73.8 & 229.3 & 134.4 & 0.13 & 91.5 \\
\hline Yields (\%) & 33.6 & 37.5 & 10.7 & 5.5 & 10.9 & 11.6 & 14.0 & 4.8 & 2.6 \\
\hline $\begin{array}{l}\text { moles } \mathrm{H}_{2} \mathrm{~mol}^{-1} \\
\text { of carbohydrate }\end{array}$ & 1.3 & 1.5 & 0.4 & 0.2 & 0.9 & 0.9 & 1.1 & 0.3 & 0.2 \\
\hline
\end{tabular}




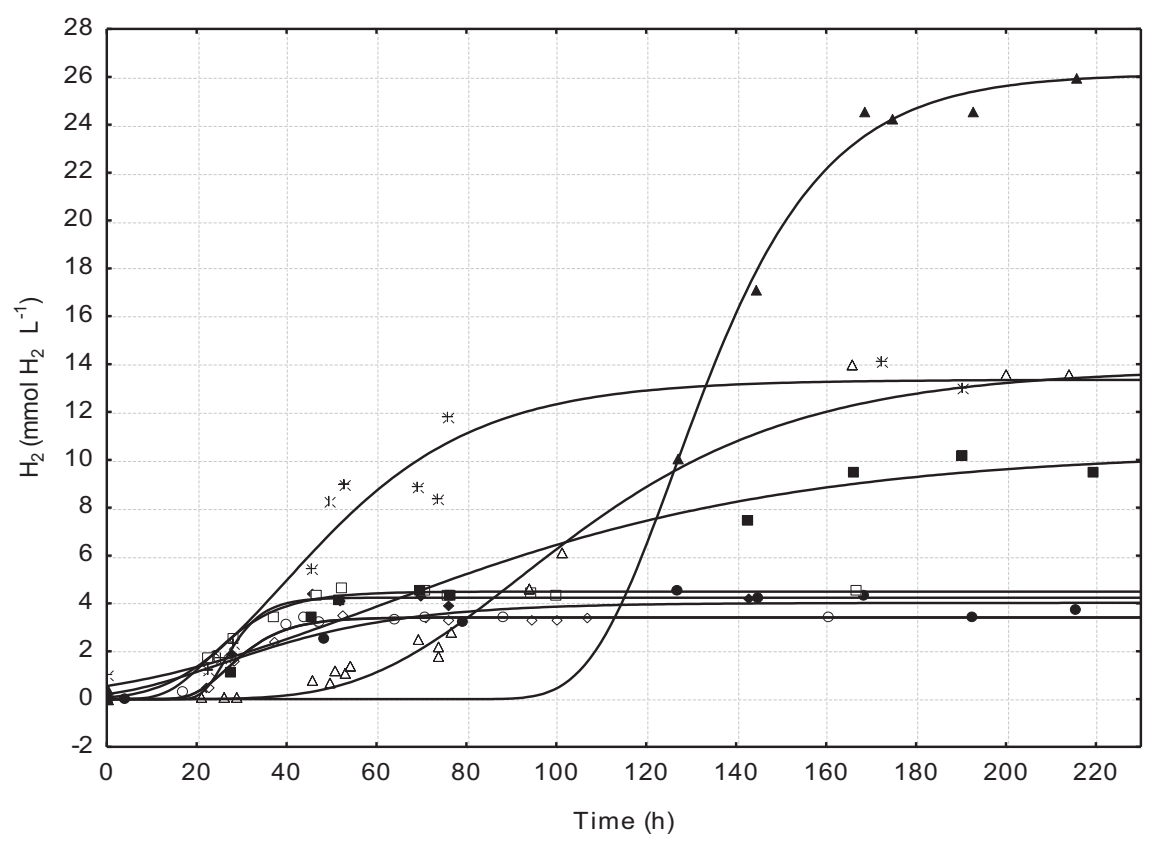

Fig. $1-\mathrm{H}_{2}$ generation in headspace of anaerobic batch reactors fed with glucose $\left[(\diamond) 2 \mathrm{~g} \mathrm{~L}^{-1} ;(\diamond) 5 \mathrm{~g} \mathrm{~L}^{-1}\right]$, sucrose $\left[(\square) 2 \mathrm{~g} \mathrm{~L}^{-1}\right.$;

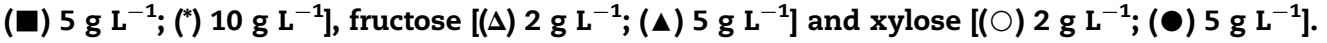

$4.2 \mathrm{mmol} \mathrm{H}_{2} \mathrm{~L}^{-1}$ with $5 \mathrm{~g} \mathrm{~L}^{-1}$ of glucose, was due to the higher concentration of glucose, that it could favor the increase of hydrogen production and due to the presence of pure culture, which allows to say that only this specie was present and that was responsible for high hydrogen generation, unlike the mixed culture in the present study that may contain consuming microorganisms of this biogas.

The $\mathrm{H}_{2}$ yields ( $\mathrm{mol} \mathrm{H}_{2} \mathrm{~mol}^{-1}$ carbohydrate) for glucose, xylose, fructose and sucrose (2.0 and $5.0 \mathrm{~g} \mathrm{~L}^{-1}$ ) was $0.4 / 0.2,0.3 /$ $0.2,1.3 / 1.5$ and $0.9 / 0.9$, respectively and assay carried out with $10 \mathrm{~g} \mathrm{~L}^{-1}$ of sucrose and was obtained $1.11 \mathrm{~mol} \mathrm{H}_{2} \mathrm{~mol}^{-1}$ of sucrose (Table 1).

There were observed sugar consumptions in all anaerobic batch reactors (Fig. 2). The reactors fed with xylose $2.0 \mathrm{~g} \mathrm{~L}^{-1}$ and glucose $2.0 \mathrm{~g} \mathrm{~L}^{-1}$ presented higher sugar consumption compared to the other reactors (Fig. 2). The percentages of consumption were $88.5 \%$ for xylose and $87.1 \%$ for glucose during 160 and $169 \mathrm{~h}$ of operation, respectively. Maintinguer et al. [13] obtained $97 \%$ of consumption of sugar in reactors fed with xylose (1848 $\mathrm{mg} \mathrm{L}^{-1}$ ) with slaughterhouse sludge as inoculum source. The authors obtained $0.2 \mathrm{~mol} \mathrm{H}_{2} \mathrm{~mol}^{-1}$ of xylose. This result of $\mathrm{H}_{2}$ yield was lower than the present study in reactor fed with $2 \mathrm{~g} \mathrm{~L}^{-1}$ of xylose $\left(0.3 \mathrm{~mol} \mathrm{H}_{2} \mathrm{~mol}^{-1}\right.$ of carbohydrate), even with a higher consumption of xylose (97\%).Maintinguer et al. [7] obtained $0.3 \mathrm{~mol} \mathrm{H}_{2} \mathrm{~mol}^{-1}$ of sucrose with $70.3 \%$ of consumption of carbon source in reactors fed with $4128 \mathrm{mg} \mathrm{L}^{-1}$ of sucrose. The sugar consumption obtained by the authors can be related due to the concentration

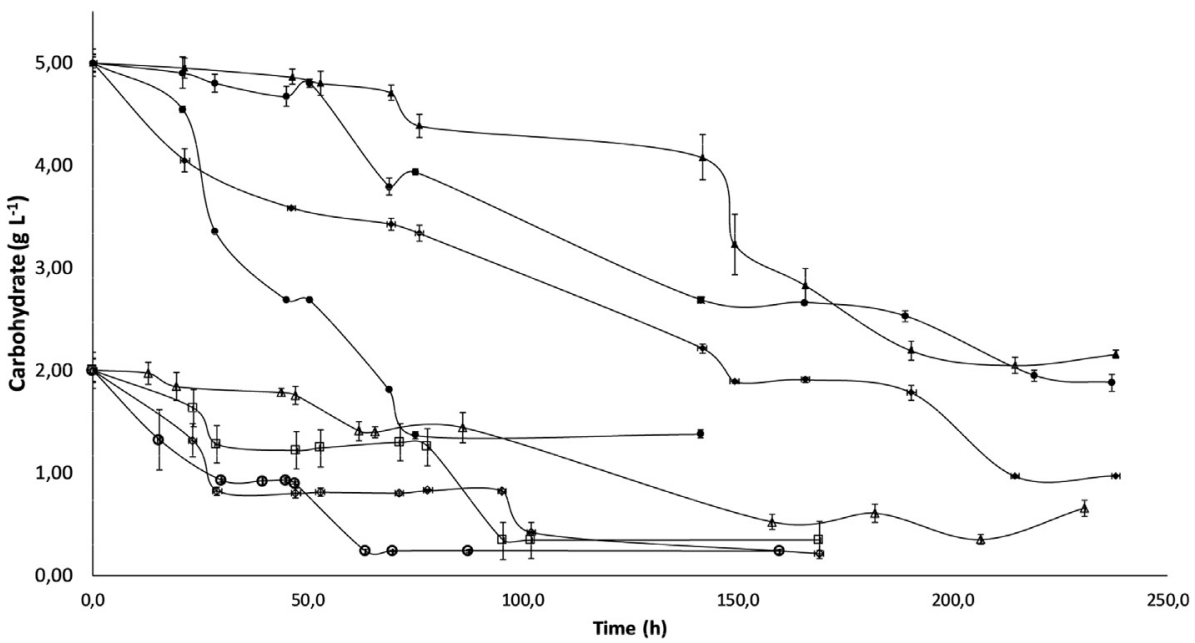

Fig. 2 - Sugar consumptions during the operation of anaerobic batch reactors fed with: glucose $\left[(\diamond) 2 \mathrm{~g} \mathrm{~L}^{-1}\right.$; ( $\left.\left.\diamond\right) \mathrm{g} \mathrm{L}^{-1}\right]$, sucrose $\left[(\square) 2 \mathrm{~g} \mathrm{~L}^{-1} ;(\square) 5 \mathrm{~g} \mathrm{~L}^{-1}\right]$, fructose $\left[(\Delta) 2 \mathrm{~g} \mathrm{~L}^{-1} ;(\Delta) 5 \mathrm{~g} \mathrm{~L}^{-1}\right]$ and xylose $\left[(\bigcirc) 2 \mathrm{~g} \mathrm{~L}^{-1} ;(0) 5 \mathrm{~g} \mathrm{~L}^{-1}\right]$. 
of sugar in the reactor, which was the highest tested and it could have acted as inhibitor for hydrogen gas production. In the present study $\left(67 \%\right.$-Sucrose $\left.5 \mathrm{~g} \mathrm{~L}^{-1}\right)$ it was obtained great values for sugar consumption close to $70 \%$, pointing to the absence of inhibition by concentration of substrates.

The best condition in this study on $\mathrm{H}_{2}$ generation was in the reactor fed with fructose $5 \mathrm{~g} \mathrm{~L}^{-1}$, obtaining a $\mathrm{H}_{2}$ yield of $1.5 \mathrm{~mol} \mathrm{H}_{2} \mathrm{~mol}^{-1}$ fructose. The maximum rates of production in $\mathrm{mmol} \mathrm{H}_{2} \mathrm{~L}^{-1} \mathrm{~h}^{-1}$ doubled from assays operated with $5.0 \mathrm{~g} \mathrm{~L}^{-1}$ fed with fructose, glucose and xylose compared to the same substrates in $2.0 \mathrm{~g} \mathrm{~L}^{-1}$ (Table 1). According to Wang \& Wei [38], the biohydrogen production follows a direct relationship with the increasing of the concentration of carbohydrates in the medium reaching a maximum point, which could act as inhibitory parameter on it.

The final pH was directly related to acetic and butyric acid generation at the end of the operation (Table 1). Reactors fed with fructose $\left(2.0\right.$ and $\left.5.0 \mathrm{~g} \mathrm{~L}^{-1}\right)$ were operated for $239 \mathrm{~h}$ and showed the higher decay of $\mathrm{pH}, 3.7$ and 3.5, respectively, which were close to the result found by Plangklang et al. [2](3.8) Hence, higher concentrations of VFAs were observed (Volatile Fatty Acids), mainly acetic acid (126.5 and $323.9 \mathrm{mg} \mathrm{L}^{-1}$ ) and butyric acid (199.9 and $296.9 \mathrm{mg} \mathrm{L}^{-1}$ ) for these reactors. Plangklang et al. [2] operated a continuous reactor at $\mathrm{pH} 6.5$, fed with sugarcane juice ( $3.2 \mathrm{~g}$ fructose $\mathrm{L}^{-1}$ ) which was inoculated Clostridium butyricum immobilized in sugarcane bagasse and they obtained acetic and butyric acid generations $\left(905 \pm 0.14 \mathrm{mg} \mathrm{L}^{-1}\right.$ and $5268 \pm 0.54 \mathrm{mg} \mathrm{L}^{-1}$, respectively) at the end of the operation. The authors have obtained yields of generation as $1.3 \mathrm{~mol} \mathrm{H}_{2} \mathrm{~mol}^{-1}$ hexose, which were lower than the present study in reactors fed with $5.0 \mathrm{~g} \mathrm{~L}^{-1}$ of fructose (1.5 $\mathrm{mol} \mathrm{H}_{2} \mathrm{~mol}^{-1}$ fructose) and generations of acetic acid $\left(323.9 \mathrm{mg} \mathrm{L}^{-1}\right)$.

The reactors fed with glucose $\left(5.0 \mathrm{~g} \mathrm{~L}^{-1}\right)$ and sucrose (5.0 $\mathrm{g} \mathrm{L}^{-1}$ ) presented generations of acetic acid (246.9 and $580.3 \mathrm{mg} \mathrm{L}^{-1}$, respectively) with yields of $0.9 \mathrm{~mol} \mathrm{H}_{2} \mathrm{~mol}^{-1}$ of glucose and $0.2 \mathrm{~mol} \mathrm{H}_{2} \mathrm{~mol}^{-1}$ of sucrose, respectively (Table 1).These higher concentrations for acetic acid could be explained due to the homoacetogenic bacteria that consume $\mathrm{H}_{2}$ to generate acetic acid [39], according to Eq. (8) [40], where $4 \mathrm{~mol}$ of hydrogen are consumed for acetic acid production. The Gibbs energy shows that the reaction can occur spontaneously. Therefore, the presence of these bacteria in the pretreated sludge can be pointed as responsible for reactors fed with glucose, fructose and sucrose $5.0 \mathrm{~g} \mathrm{~L}^{-1}$ to present higher concentrations of acetic acid. Homoacetogenic bacteria are recognized as spore-forming, such as Clostridium species [40], and, therefore, resistant to heat treatment that was applied in this study.

$2 \mathrm{HCO}_{3}^{-}+4 \mathrm{H}_{2}+\mathrm{H}^{+} \rightarrow \mathrm{CH}_{3} \mathrm{COO}^{-}+\mathrm{H}_{2} \mathrm{O} \quad \Delta \mathrm{G}^{0}=-105 \mathrm{~kJ}$

The results obtained in the present study were compared to the literature (Table 2). Fang et al. [6] operated a continuous batch reactor fed with $7.0 \mathrm{~g} \mathrm{~L}^{-1}$ of glucose at $36^{\circ} \mathrm{C}$ and $\mathrm{pH} 5.5$ with $6 \mathrm{~h}$ of retention time for over 60 days and the results obtained (1.1 mol H $\mathrm{mol}^{-1}$ glucose) were similar to the present study for the reactor fed with sucrose $10 \mathrm{~g} \mathrm{~L}^{-1}$. Subudhi et al. [22] operated batch reactors fed with $10 \mathrm{~g} \mathrm{~L}^{-1}$ of glucose for $24 \mathrm{~h}$ at $37^{\circ} \mathrm{C}$ and $\mathrm{pH} 7.0$ and obtained higher results $(1.4 \mathrm{~mol}$ $\mathrm{H}_{2} \mathrm{~mol}^{-1}$ of glucose) than the present study. However, the authors applied pH 7,0 that is ideal for growth of anaerobic hydrogen producers. Plangklang et al. [2] operated anaerobic batch reactors fed with $3.2 \mathrm{~g} \mathrm{~L}^{-1}$ of fructose at $37{ }^{\circ} \mathrm{C}$ for $24 \mathrm{~h}$ in an orbital shaker at $150 \mathrm{rpm}$ at $\mathrm{pH} 6.5$ and obtained lower yields (1.3 $\mathrm{mol} \mathrm{H}_{2} \mathrm{~mol}^{-1}$ fructose) than the present study (1.5 $\mathrm{mol} \mathrm{H}_{2} \mathrm{~mol}^{-1}$ fructose). Maintinguer et al. [7] operated an anaerobic batch reactor fed with $4.2 \mathrm{~g} \mathrm{~L}^{-1}$ sucrose for $222 \mathrm{~h}$, at pH 5.5, at $37^{\circ} \mathrm{C}$ and obtained lower yields $\left(0.3 \mathrm{~mol} \mathrm{H}_{2} \mathrm{~mol}^{-1}\right.$ of sucrose) than the present study (1.0 $\mathrm{mol} \mathrm{H}_{2} \mathrm{~mol}^{-1}$ sucrose). The present study obtained similar and better results than the authors already cited for reactors with fructose $\left(5 \mathrm{~g} \mathrm{~L}^{-1}\right)$ and sucrose (5 and $\left.10 \mathrm{~g} \mathrm{~L}^{-1}\right)$.

\section{Bioinformatics}

Were obtained 200 clones from the anaerobic bacteria consortium, resulting in 96 sequences from molecular biology analysis. These sequences were grouped in 8 Operational Taxonomic Unit (OTU) and they have revealed belonging to Firmicutes phylum: Veillonella sp., Streptococcus sp. and uncultured bacteria (Table 3).

Most of the sequences (71\%) were affiliated as Veillonella sp. which are anaerobic gram-negative cocci no spore forming. They can be present in anaerobic $\mathrm{H}_{2}$ producing bioreactors [41-44] degrading glucose or lactate to generate acetic, propionic and lactic acids [42]. In addition, Veillonellaceae family has a potential for hydrogen production being reported as lactic acid consumers [44-46]. Rosa et al. [41] obtained similarity with Veillonellaceae family as the present study during the operation anaerobic fluidized bed reactor (AFBR) with pig breeding and poultry wastes fed with cheese whey wastewater $\left(5 \mathrm{~g} \mathrm{~L}^{-1}\right)$ and they obtained similar yields of $1.33 \mathrm{~mol} \mathrm{H}_{2}$

Table 2 - Comparison of hydrogen yields presented by mesophilic conditions.

\begin{tabular}{llll} 
Authors & \multicolumn{1}{c}{ Substrate } & \multicolumn{1}{c}{ Conditions } & $\mathrm{mol} \mathrm{H}_{2} \mathrm{~mol}^{-1} \mathrm{carbohydrate}^{-}$ \\
\hline$[19]$ & Glucose $10 \mathrm{~g} \mathrm{~L}^{-1}$ & Batch $-37^{\circ} \mathrm{C}$ & 1.4 \\
{$[6]$} & Sucrose $4.2 \mathrm{~g} \mathrm{~L}^{-1}$ & Batch $-37^{\circ} \mathrm{C}$ & 0.3 \\
{$[5]$} & Glucose $7 \mathrm{~g} \mathrm{~L}^{-1}$ & Continuous Batch $-36{ }^{\circ} \mathrm{C}$ & 1.1 \\
{$[2]$} & Fructose $3.2 \mathrm{~g} \mathrm{~L}^{-1}$ & Batch $-37{ }^{\circ} \mathrm{C}$ & 1.3 \\
The present study & Fructose $5 \mathrm{~g} \mathrm{~L}^{-1}$ & Batch $-37^{\circ} \mathrm{C}$ & 1.5 \\
& Sucrose $5 \mathrm{~g} \mathrm{~L}^{-1}$ & & 1.0 \\
& Sucrose $10 \mathrm{~g} \mathrm{~L}^{-1}$ & & 1.1 \\
\hline
\end{tabular}


Table 3 - Phylogenetic distribution from anaerobic bacteria consortium.

\begin{tabular}{|c|c|c|c|c|c|c|}
\hline OTU & $\mathrm{N}^{\circ}$ of sequences & Affiliation & Access & Phylum & Similarity (\%) & $\mathrm{N}^{\circ}$ of base pairs \\
\hline 1 & 65 & Veillonella sp. & JN695643.1 & Firmicutes & 99 & 1230 \\
\hline 2 & 4 & Veillonella sp. & HQ616396.1 & Firmicutes & 99 & 1269 \\
\hline 3 & 2 & Uncultured & HM811978.1 & Firmicutes & 93 & 1238 \\
\hline 4 & 2 & Uncultured & JQ470836.1 & Firmicutes & 95 & 1201 \\
\hline 5 & 1 & Uncultured & JQ470836.1 & Firmicutes & 97 & 1268 \\
\hline 6 & 13 & Streptococcus parasanguinis & NR_074109.1 & Firmicutes & 99 & 1210 \\
\hline 7 & 8 & Uncultured & JF114361.1 & Firmicutes & 99 & 1236 \\
\hline 8 & 3 & Streptococcus salivarius & AB680534.1 & Firmicutes & 99 & 1271 \\
\hline
\end{tabular}

$\mathrm{mol}^{-1}$ lactose; with generations of ethanol, acetic and butyric acids as the present study. Luo et al. [43] identified Veillonellaceae family bacteria in anaerobic reactors fed with glucose as substrate and they obtained $2.8 \mathrm{~mol} \mathrm{H}_{2} \mathrm{~mol}^{-1}$ glucose. Shida et al. [42] also observed similarity to Veillonellaceae family in a reactor fed with glucose $\left(2 \mathrm{~g} \mathrm{~L}^{-1}\right)$ with yields of $1.9 \mathrm{~mol} \mathrm{H}_{2} \mathrm{~mol}^{-1}$ glucose. Veillonellaceae family can tolerate high concentrations of organic acids and can be considered as helpers in the bioH $_{2}$ reactors, stabilizing the process among the mix culture [44]. In the present study high generations of organic fatty acids were observed, according to what was described previously, and it can confirm Veillonellaceae family identified were involved in biologic process of $\mathrm{H}_{2}$.

About $16 \%$ of the sequences distributed in OTUs 6 and 8 have shown phylogenetic similarity to Streptococcus sp. Hung et al. [11] observed hydrogen gas production in anaerobic reactors with a mix culture of Clostridium sp. and Streptococcus sp., in anaerobic granules. According to Davila-Vazques et al. [47] and Fang et al. [6] the existence of Streptococcaceae family in reactors while hydrogen producing is rising could occur, however, this evidence was not confirmed for hydrogen production. Wu et al. [48] has operated a sequencing batch reactor (SBR) with immobilized sludge in heat pretreated silicon (100 ${ }^{\circ} \mathrm{C}$ for $20 \mathrm{~min}$ ) fed with sucrose $\left(8.9-35.6 \mathrm{~g} \mathrm{~L}^{-1}\right.$ ) and they obtained $3.5 \mathrm{~mol} \mathrm{H}_{2} \mathrm{~mol}^{-1}$ sucrose. After pretreatment of the inoculum similarity with Clostridium sp., Klebsiella sp. and Streptococcus sp. were observed by biomolecular analyses. Fang et al. [6] observed Clostridiaceae, Enterobacteriaceae and $3.1 \%$ of Streptococcus bovis in continuous flow stirred-tank reactor (CSTR) fed with glucose at $\mathrm{pH} 5.5,36^{\circ} \mathrm{C}, 6.6 \mathrm{~h}$ of hydraulic retention, generating $\mathrm{H}_{2}$. Linet al. [49] obtained yields of $1.1 \mathrm{~mol} \mathrm{H}_{2} \mathrm{~mol}^{-1}$ hexose and similarity with Clostridium butyricum, Clostridium pasteurianum, Klebsiella pneumoniae, Streptococcus sp. and Pseudomonas sp in anaerobic batch reactors from starch $\left(20 \mathrm{~g} \mathrm{COD} \mathrm{L}^{-1}\right)$, at $35^{\circ} \mathrm{C}$, pH 5.5 with inoculum from a biologic treatment of paper industry. In the present study, morphologies of cocci chain such as Streptococcus sp were observed. However, Streptococcus sp. are found in anaerobic bioreactors $\mathrm{H}_{2}$ producing [50] and they can coexist with Clostridium sp, after heat-treatment of inocula to degrade glucose and sucrose $[6,11,47]$ as observed in the present study.

Only $13 \%$ of the sequences were affiliated as uncultured bacteria. Probably the Gram-positive rods spore forming observed in the microscopic analysis during the operation of anaerobic reactors were affiliated as uncultured bacteria from Firmicutes Phylum.
The diversity of anaerobic bacteria from a subtropical sludge verified in this study reinforces the viability of its applicability on biohydrogen producing under mesophilic conditions.

\section{Conclusions}

The heat treatment applied to the inoculum was effective in inactivating hydrogen consumers such as methanogenic archaea.

Fructose showed a high potential of biohydrogen generation.

The biological production of $\mathrm{H}_{2}$ was due to the anaerobic bacteria consortium from the subtropical brewery sludge identified as Firmicutes Phylum, mainly Veillonella sp. Streptococcus sp. and uncultured bacteria.

The sludges from subtropical countries such as Brazil treating brewery wastes can be applied on biohydrogen production using wastewaters with low concentrations of sugars.

\section{Acknowledgments}

The authors gratefully acknowledge Fundação de Amparo à Pesquisa do Estado de São Paulo (FAPESP Processes 2012/ 01318-01, 2013/03815-5 and 2017/11767-1) and Fundação para o Desenvolvimento da Unesp (Fundunesp) for the financial support (Process 1001/2003); Center for Monitoring and Research of the Quality of Fuels, Biofuels, Crude Oil and Derivatives (CEMPEQC) for equipment used during the study.

\section{R E F E R E N C E S}

[1] Xia A, Jacob A, Herrmann C, Murphy JD. Fermentative biohydrogen production from galactose. Energy 2016;96:346-54. https://doi.org/10.1016/j.energy.2015.12.087.

[2] Plangklang P, Reungsang A, Pattra S. Enhanced bio-hydrogen production from sugarcane juice by immobilized Clostridium butyricum on sugarcane bagasse. Int J Hydrogen Energy 2012;37:15525-32. https://doi.org/10.1016/j.ijhydene.2012. 02.186.

[3] Poleto L, Souza P, Magrini FE, Beal LL, Rodrigues Torres AP, Paula De Sousa M, et al. Selection and identification of microorganisms present in the treatment of wastewater and activated sludge to produce biohydrogen from glycerol. Int J 
Hydrogen Energy 2016;41:4374-81. https://doi.org/10.1016/ j.ijhydene.2015.06.051.

[4] Argun H, Dao S. Bio-hydrogen production from waste peach pulp by dark fermentation: effect of inoculum addition. Int J Hydrogen Energy 2017;42:2569-74. https://doi.org/10.1016/ j.ijhydene.2016.06.225.

[5] Maintinguer SI, Sakamoto IK, Adorno MAT, Varesche MBA. Bacterial diversity from environmental sample applied to bio-hydrogen production. Int J Hydrogen Energy 2015;40:3180-90. https://doi.org/10.1016/j.ijhydene.2014. 12.118.

[6] Fang HHP, Zhang T, Liu H. Microbial diversity of a mesophilic hydrogenproducing sludge. Appl Microbiol Biotechnol 2002;58:112-8.

[7] Maintinguer SI, Fernandes BS, Duarte IC, Saavedra NK, Adorno MAT, Varesche MB, et al. Fermentative hydrogen production by microbial consortium. Int J Hydrogen Energy 2008;33:4309-17. https://doi.org/10.1016/j.ijhydene.2008. 06.053.

[8] Santos SC, Rosa PRF, Sakamoto IK, Varesche MBA, Silva EL. Organic loading rate impact on biohydrogen production and microbial communities at anaerobic fluidized thermophilic bed reactors treating sugarcane stillage. Bioresour Technol 2014;159:55-63. https://doi.org/10.1016/j.biortech.2014. 02.051.

[9] Maintinguer SI, Lazaro CZ, Pachiega R, Varesche MBA, Sequinel R, de Oliveira JE. Hydrogen bioproduction with Enterobacter sp. isolated from brewery wastewater. Int J Hydrogen Energy 2017;42:152-60. https://doi.org/10.1016/ j.ijhydene.2016.11.104.

[10] Pattra S, Sangyoka S, Boonmee M, Reungsang A. Biohydrogen production from the fermentation of sugarcane bagasse hydrolysate by Clostridium butyricum. Int J Hydrogen Energy 2008;33:5256-65. https://doi.org/10.1016/ j.ijhydene.2008.05.008.

[11] Hung C-H, Cheng C-H, Guan D-W, Wang S-T, Hsu S-C, Liang C-M, et al. Interactions between Clostridiumsp. and other facultative anaerobes in a self-formed granular sludge hydrogen-producing bioreactor. Int J Hydrogen Energy 2011;36:8704-11. https://doi.org/10.1016/ j.ijhydene.2010.06.010.

[12] Das D, Veziroglu TN. Hydrogen production by biological processes: a survey of literature. Int J Hydrogen Energy 2013;26:13-28.

[13] Maintinguer SI, Fernandes BS, Duarte ICS, Saavedra NK, Adorno MAT, Varesche MBA. Fermentative Hydrogen production with xylose by Clostridium and Klebsiella species in anaerobic batch reactors. Int J Hydrogen Energy 2011;36:13508-17. https://doi.org/10.1016/j.ijhydene. 2011.07.095.

[14] Huang C, Zeng G, Huang D, Lai C, Xu P, Zhang C, et al. Effect of Phanerochaete chrysosporium inoculation on bacterial community and metal stabilization in lead-contaminated agricultural waste composting. Bioresour Technol 2017. https://doi.org/10.1016/j.biortech.2017.06.124.

[15] Torquato LDM, Pachiega R, Crespi MS, Nespeca MG, de Oliveira JE, Maintinguer SI. Potential of biohydrogen production from effluents of citrus processing industry using anaerobic bacteria from sewage sludge. Waste Manag 2017;59:181-93. https://doi.org/10.1016/j.wasman.2016. 10.047 .

[16] Abastecimento. CN de. Acompanhamento de safra brasileira: cana-de-açúcar, segundo levantamento, agosto/2012Companhia Naciional de Abastecimento. Brasília: Conab; 2012. p. 2013.

[17] Lazaro CZ, Perna V, Etchebehere C, Varesche MBA. Sugarcane vinasse as substrate for fermentative hydrogen production: the effects of temperature and substrate concentration. Int J Hydrogen Energy 2014;39:6407-18.

https://doi.org/10.1016/j.ijhydene.2014.02.058.

[18] Wilkie AC, Riedesel KJ, Owens JM. Stillage characterization and anaerobic treatment of ethanol stillage from conventional and cellulosic feedstocks. Biomass Bioenergy 2000;19:63-102. https://doi.org/10.1016/S0961-9534(00)00017-9.

[19] Dos Reis CM, Carosia MF, Sakamoto IK, Amâncio Varesche MB, Silva EL. Evaluation of hydrogen and methane production from sugarcane vinasse in an anaerobic fluidized bed reactor. Int J Hydrogen Energy 2015;40:8498-509. https:// doi.org/10.1016/j.ijhydene.2015.04.136.

[20] Silva CAF e, Bueno JM, Neves MR. The pulp and paper industry in Brazil. Guia ABTCP-FORNECEDORES \& FABRICANTES - Celulose E Pap. 2016. p. 14-26.

[21] Siqueira MR. Efeito dos produtos de hidrólise de materiais lignocelulósicos sobre a produção de H 2 por fermentação. Universidade de São Paulo; 2015.

[22] Subudhi S, Nayak T, Ram Kumar N, Vijayananth P, Lal B. Impact of regulated $\mathrm{pH}$ on proto scale hydrogen production from xylose by an alkaline tolerant novel bacterial strain, Enterobacter cloacae DT-1. Int J Hydrogen Energy 2013;38:2728-37. https://doi.org/ 10.1016/j.ijhydene.2012.12.036.

[23] Kim DH, Han SK, Kim SH, Shin HS. Effect of gás sparging on continuous fermentative hydrogen production. Int $J$ Hydrogen Energy 2006;31:2158-69.

[24] APHA AWWA WEF. Standard methods for the examination of water and wastewater. 20th ed. Washington, D.C. American Public Health Association; 2005.

[25] Del Nery V. Utilização de lodo anaeróbio imobilizado em gel no estudo da partida de reatores de fluxo ascendente com manta de lodoe. Universidade de São Paulo; 1987.

[26] Pachiega Renan, Maintinguer Sandra I, Sequinel Rodrigo, de Oliveira José Eduardo, GB. Diversidade de bactérias produtoras de $\mathrm{H} 2$ proveniente de águas residuárias de cervejaria. In: Congr. Iniciação Científica da UNESP, XXVI CIC 2014, Águas Lindóia, Brazil, Novemb. 2014, Proc. Araraquara: UNESP; 2014.

[27] Dhole V, Kadam V. Advantages of the TOGA-transformer oil gas analyzer involving headspace-GC analysis and a DGA system. Application note 10348. Nasik, India: Thermo Fisher Scientific; 2012.

[28] Adorno MAT, Hirasawa JS, Varesche MBA. Development and validation of two methods to quantify volatile acids (C2-C6) by GC/FID: headspace (automatic and manual) and liquidliquid extraction (LLE). Am J Anal Chem 2014;5:406-14. https://doi.org/10.4236/ajac.2014.57049.

[29] Dubois M, Gilles KA, Hamilton JK, Rebers PA, Smith F. Colorimetric method for determination of sugars and related substances. Anal Chem 1956;28:350-6.

[30] Herbert D, Philipps OS, Strang R. Carbohydrate analysis. Methods Enzym. SB. 1971. p. 265-77.

[31] Lay JY, Li YY, Noike T. Developments of bacterial population and methanogenic activity in a laboratory-scale landfill bioreactor. Water Res 1998;32:3673-9.

[32] Russell JFS, DW. Molecular cloning: a laboratory manual. Mol. Cloning A Lab. Man. 3 ed. Cold Spring Harbor Laboratory Press; 2001. p. 2100.

[33] Griffiths RI, Whiteley AS, O'donnell AG. Rapid Method for coextration of DNA from natural environments for analysis of ribosomal DNA and rRNA-based microbial community composition. Appl Environ Microbiol 2000;66:5488-91.

[34] Lane D. 16S/23S rRNA sequencing. Nucleic Acid Tech. Bact. Syst. E. Stackeb. 1991. p. 115-75.

[35] Song ZX, Dai Y, Fan QL, Li XH, Fan YT, Hou HW, et al. Effects of pretreatment method of natural bacteria source on microbial community and biohydrogen production by dark fermentation. Int J Hydrogen Energy 2012;37:5631-6. https:// doi.org/10.1016/j.ijhydene.2012.01.010. 
[36] SÁ LRV, Cammarota MC, Oliveira TC, Oliveira EMM, Matos A, Ferreira-Leitão VS. Pentoses, hexoses and glycerin as substrates for biohydrogen production: an approach for Brazilian biofuel integration. Int J Hydrogen Energy 2013;38:2986-97.

[37] Kawagoshi Y, Hino N, Fujimoto A, Nakao M, Fujita Y, Sugimura SFK. Effect of seed sludge conditioning on hydrogen fermentation and $\mathrm{pH}$ effect on bacterial community relevant to hydrogen production. J Biosci Bioenginneering 2005;100:524-30.

[38] Wang J, Wan W. The effect of substrate concentration on biohydrogen production by using kinetic models. Sci China Ser B Chem 2008;51:1110-7. https://doi.org/10.1007/s11426008-0104-6.

[39] Rodrigues CV, Santana KO, Nespeca MG, Eduardo de Oliveira J, Maintinguer SI. Crude glycerol by transesterification process from used cooking oils: characterization and potentialities on hydrogen bioproduction. Int J Hydrogen Energy 2016;41:14641-51. https://doi.org/10.1016/j.ijhydene.2016.06.209.

[40] Ito T, Nakashimada Y, Senba K, Matsui T, Nishio N. Hydrogen and ethanol production from glycerol-containing wastes discharged after biodiesel manufacturing process. J Biosci Bioeng 2005;100:260-5. https://doi.org/10.1263/ jbb.100.260.

[41] Rosa PRF, Santos SC, Sakamoto IK, Varesche MBA, Silva E. Hydrogen production from cheese whey with etanol-type fermentation: effect of hydrogen retention time on the microbial community composition. Bioresour Technol 2014;161:10-9. https://doi.org/10.1016/j.biortech.2014.03.020.

[42] Shida GM, Sader LT, Amorim ELC, Sakamoto IK, Maintinguer SI, Saavedra NK, et al. Performance and composition of bacterial communities in anaerobic fluidized bed reactors for hydrogen production: effects of organic loading rate and alkalinity. Int J Hydrogen Energy 2012;37:16925-34.
[43] Luo Y, Zhang H, Salerno M, Logan BE, Bruns MA. Organic loading rates affect composition of soil-derived bacterial communities during continuous, fermentative biohydrogen production. Int J Hydrogen Energy 2008;33:6566-76.

[44] Etchebehere C, Castelló E, Wenzel J, del Pilar Anzola-Rojas M, Borzacconi L, Buitrón G, et al. Microbial communities from 20 different hydrogen-producing reactors studied by 454 pyrosequencing. Appl Microbiol Biotechnol 2016;100:3371-84. https://doi.org/10.1007/s00253-016-7325-y.

[45] Silva-Illanes F, Tapia-Venegas E, Toledo-Alarcón J, RuizFilippi G. Producción de hidrogeno a partir de glicerol mediante uma etapa inicial de enriquecimento aeróbio del inóculo. XI Simp. Latinoam. Dig. Anaerobia, La Habana. 2014.

[46] Castelló E, Santos CG, Iglesias T, Paolino G, Wenzel J, Borzacconi L, et al. Feasibility of biohydrogen production from cheese whey using a UASB reactor: links between microbial community and reactor performance. Int J Hydrogen Energy 2009;34:5674-82.

[47] Davila-Vazquez G, Cota-Navarro CB, Rosales-Colunga LM, De León-Rodríguez A, Razo-Flores E. Continuous biohydrogen production using cheese whey: improving the hydrogen production rate. Int J Hydrogen Energy 2009;34:4296-304.

[48] Wu SY, Hung CH, Lin CN, Chen HW, Lee AS, Chang CJ. Fermentative hydrogen production and bacterial community structure in high-rate anaerobic bioreactors containing silicone-immobilized and self-flocculated sludge. Wiley Period Inc; 2005.

[49] Lin CY, Chang CC, Hung CH. Fermentative hydrogen production from starch using natural mixed cultures. Int J Hydrogen Energy 2008;33:2445-53. https://doi.org/10.1016/ j.ijhydene.2008.02.069.

[50] Hawkes FR, Hussy I, Kyazze G, Dinsdale R, Hawkes DL. Continuous dark fermentative hydrogen production by mesophilic microflora: principles and progress. Int J Hydrogen Energy 2007;32:172-84. 